\title{
THE IMPACT OF THE NEW PUBLIC GOVERNANCE MODEL FOR THE MODERNIZATION OF MUSEUMS
}

Rytis Milkintas, Master of Public Administration, Šiauliai University, Lithuania, 1995rytis@gmail.com

\begin{abstract}
The aim of the article is to reveal the influence of the new public governance model applied in the public sector on the modernization processes of museums. The article discusses the essential principles of the new public governance model: abandonment of the hierarchical model (transition to horizontal management), cross-sectoral cooperation (networking), customer orientation (visitors), increasing inclusion, transparency of activities, updating of accountability. The connections of the named principles with the modernizing management of museum activities and organization are revealed. The most important changes in the field of museum management are discussed with the help of the essential legal acts of the Republic of Lithuania regulating the activities of museums and statistical data. The mechanisms of the new public governance model already implemented in the museum sector and the results of their application are highlighted: new and innovative factors that increase the efficiency of museum management, visitor involvement, and institutional attractiveness have emerged.
\end{abstract}

Key words: new public governance, museum's modernization, networking.

\section{INTRODUCTION}

In the second half of the 20th century, with the beginning of rapid processes of change in the political field, the development of public sector governance models, legal and social systems, it also led to the beginning of changes in museum institutions. Museum institutions often have a long, gradual system of governance, the principles of which have been determined by the mechanisms of operation of museums that have developed over several decades or even centuries. According to the nature of their activities, museum institutions have functioned as inert cultural organizations for many decades, but especially with the acceleration of globalization and change of governance models in recent decades, museum institutions have to adapt to ongoing changes in order to survive. The aim of the article is to reveal the links between the new public governance model applied in the public sector and the impact on museum modernization processes. The basic functions of the public governance model are 
gradually entering and changing the governance mechanisms of museums. It is important to emphasize that the majority of museums operating in Lithuania are state museums, which are driven by public sector cultural field management institutions, therefore the principles of the new public governance have an even greater impact on museum change and modernization processes in the following six areas of management and activity: horizontal management), cross-sectoral cooperation (networking), citizens orientation (visitor), inclusion, transparency of activities, updating of accountability. It is important to emphasize that the field of the relationship between the new public administration as one of the models of public administration and the processes of museum modernization has been little researched and analyzed in the scientific literature.

\section{FORMATION AND DEVELOPMENT OF A NEW PUBLIC GOVERNANCE MODEL}

The rapid change and development of public administration models is significantly influenced by the ever-accelerating processes of globalization, changes in the political situation in the countries, and changes in social models. According to Milkintas (2020): "The change of public administration models from the traditional Max Weber bureaucratic model of public administration to the new public governance model has come a long way not only in terms of historical development, but also the abundance of changes in public administration." These changes presupposed the continuous improvement of public sector and public interest budgetary institutions in order to adapt to rapidly changing market conditions. According to Pedersen, Johannsen (2018) "The new public governance approach advocates a more flexible and participatory public administration as means to higher efficiency and increased legitimacy." According to Guogis (2010), the new public governance “< $<>$ emphasizes horizontal governance, greater citizen participation in governance, prevention of corruption, polycentric democracy, transparency, accountability, inter-institutional cooperation and the active involvement of non-governmental organizations ". The table below highlights the key features of the new public governance model and the general principles that characterize the public administration model being analyzed.

Table 1 New public governance model characteristics

\begin{tabular}{|l|l|l|l|l|}
\hline \multicolumn{2}{|l|}{ New public governance (NPG) } \\
\hline $\begin{array}{l}\text { Referenc } \\
\boldsymbol{e} \\
\text { features }\end{array}$ & Creating value for society & $\begin{array}{l}\text { Horizontal } \\
\text { management }\end{array}$ & $\begin{array}{l}\text { Interinstitutio } \\
\text { nal } \\
\text { cooperation }\end{array}$ & $\begin{array}{l}\text { Citizen } \\
\text { participation }\end{array}$ \\
\hline
\end{tabular}




\begin{tabular}{|c|c|c|c|c|}
\hline \multirow{3}{*}{$\begin{array}{l}\text { General } \\
\text { principle } \\
\mathrm{s}\end{array}$} & $\begin{array}{l}\text { Fighting priorities with } \\
\text { negatives } \\
\text { phenomena } \\
\text { reasons, but not with } \\
\text { consequences }\end{array}$ & Cooperation & $\begin{array}{l}\text { Creating } \\
\text { value for } \\
\text { citizens }\end{array}$ & $\begin{array}{l}\text { Involving citizens } \\
\text { in public } \\
\text { matters }\end{array}$ \\
\hline & Effectiveness & $\begin{array}{l}\text { Service, not } \\
\text { regulation }\end{array}$ & Effectiveness & $\begin{array}{l}\text { Confidence in } \\
\text { government and } \\
\text { institution building }\end{array}$ \\
\hline & $\begin{array}{l}\text { Strategic thinking, } \\
\text { democratic functioning }\end{array}$ & $\begin{array}{l}\text { Serving the } \\
\text { citizens, not } \\
\text { customers }\end{array}$ & $\begin{array}{l}\text { The } \\
\text { importance of } \\
\text { networking in } \\
\text { creating } \\
\text { added value }\end{array}$ & $\begin{array}{l}\text { Assessing } \\
\text { citizenship more } \\
\text { for management }\end{array}$ \\
\hline
\end{tabular}

Source: compiled by the author based on Scholl H. J. ir Scholl M. C., (2014); Morgan ir Shinn, (2014); Stanislovaitiene, (2016); Bolivar, Meijer (2015).

According to Jonikaitè, Juknevičienè, Mikolaityte (2016), the transition of the new public management model to the new public governance model, the main features of which are presented in the table, brought three essential changes: 1) "changing direction of activity" (entrepreneurship-based activities are reoriented towards the creation of public goods for society (actualization of added value growth), updating sustainable development, which increases public confidence in public sector institutions); 2) "End of emphasis on crosssectoral competition" (in the presence of a clear separation of the public and private sectors, a gradual increase of mutual cooperation is actualized - a network of cooperation based on networking, which significantly accelerates and streamlines the activities of public sector institutions); 3) "Changing the system of subordination and maintaining interoperability" (gradual change from a hierarchical management model, also called a vertical management model, to a horizontal management model, the essence of which is the updating of network based operations within and outside the organization, the control principles applied in the organization are replaced by negotiations, the search for compromises, the evaluation of employees as a factor determining the organization 's success increases significantly).

The processes of change in the public sector are significantly influenced by rapidly changing technologies, which inevitably led to the emergence of new public governance. According to Vincente, Camarero, Garrido (2012), technology enables and determines one of the fundamental features of the analyzed public administration model - the ability to adapt quickly and efficiently to changing environmental conditions, and thus ensure the quality and 
efficiency of public service delivery. An integral part of the change in the discovery of the new public governance model is the delegation of decision making by the central government to local authorities. These changes are becoming a counterweight to traditional hierarchical processes of public administration. Mentioned steps of change enabled the emergence of the phenomenon of decentralization in the public sector (Howlett, Kekez, Poocharoen, 2017). The development and strengthening of cooperation links between public and private actors is becoming an integral part of decentralization processes. According to Frederickson (2016), the emergence of horizontal governance has significantly stimulated and accelerated the development of collaborative relationships that are systematically nurtured into sustainable networking relationships. This author also highlighted another very important aspect of sustainable cooperation - shared responsibility. In the course of cooperation, the parties shall base their contractual relations on the obligations of both parties, which lead to an increase in the quality of the joint products created. It is important to emphasize that the application of networking processes at the local government level increases decentralization - local authorities become less dependent on central governments, as at the local level they have a network of partner institutions that help to implement joint activities, projects of various spectrum.

Networking processes are inseparable from the involvement of civil society in the assessment, delivery and even implementation of the quality of public services (Strokosch, Osborne 2020). Citizen involvement in public sector activities under the new public governance model is analyzed by Bovaird, Loeffler (2012), Bovaird, Ryzin, Loeffler et al. (2015). These authors argue that the involvement of a strong civil society in the activities of public sector institutions improves the quality of political processes, and at the same time promotes the growth of public maturity. Greater stakeholder involvement in public sector processes promotes two other very important components of public sector control mechanisms: transparency and accountability. The application of these control mechanism measures in the activities of public sector institutions not only significantly contributes to the increase of the quality of the performed activities, but also promotes public confidence in the activities performed by the government or budgetary institutions. This aspect is very important, as the application of the new public management model by public authorities, which has encouraged the use of entrepreneurial processes, has significantly reduced public confidence in public authorities over a number of decades. Restoring public confidence is therefore crucial. In the second part of the article, it is expedient to review the expressions of 
the features and characteristics of the new public governance model in the activities of museums.

\section{THE INFLUENCE OF THE NEW PUBLIC GOVERNANCE ON THE PROCESSES OF CHANGE IN MUSEUM MANAGEMENT}

The orientation of museum activities towards the satisfaction of public interests, publicity of collections, accessibility and its management has changed significantly since the emergence of the museum phenomenon. According to Milkintas (2020), the "beginning of the creation of museums as a phenomenon dates back to the 16th -17 th centuries. This phenomenon originated in Germany, but quickly spread to other Western European countries. The origins of art collecting are linked to the emergence of Kunstkammer. Kunstkammer is literally translated as an "art room". It is very important to mention that such private museums were created in the houses of nobles and symbolized power, level of development, but such museums were accessible only to a very small part of society - the nobility. Later at XIX-XX century the establishment of state museums was started, which opened their collections to the public. The management of museums is constantly changing these days, adapting to the management models applied in the states, therefore it is expedient to review the changes that the new public governance model has brought to the operation and management of museums. ICOM (International Council of Museums) is the central organisation of the museum's coordinating, long-term vision creator of the museum institution. Founded in 1947, this organization has developed a network of international and national committees in the states and unites more than 45,000 thousand museologists from around the world. The activities of this organization reflect the principles of operation of the new public governance model - the aim is to increase the accessibility of museum expositions and funds to the public, to modernize museum management processes by optimizing them. In its statute (2007), ICOM also refines the concept of a modern museum: "museum is a non-profit, public institution that constantly serves society and its development, acquires, preserves, researches, communicates and exhibits the tangible and intangible heritage of mankind for scientific, study and leisure purposes." The concept of a museum institution presented by ICOM in 2007 clearly reflects the principles of the new public governance - service to the public (ensuring the public interest), non-profit (creation of public goods), communication (development of cooperation). The presented concept reflects the implementation of the vision of a modern museum and significant positive changes compared to the concept of museums published by 
ICOM in 1961, the essential axis of which is the collection and restoration of museum exhibits.

The processes of museum change, which are also reflected in the concepts presented by ICOM discussed earlier, are promoted by the rapid development of technology, the influence of the media, changes in the creation and availability of information, and changes in political systems and legal frameworks. Anderson (2012) distinguishes four groups of change, the choirs are characterized by the features of a modern museum: management principles (application of horizontal management principles to take into account the insights, experience of a wide range of employees), institutional values (the museum must have a clear set of values - vision, mission ), internal and external communication (development of effective communication networks within the internal structure of the organization and with museum visitors), application of management tools (use the most optimal management tools according to the nature of activities and thus remain competitive in the cultural field). The broader characteristics of the management interface of a modern modernizing museum with the new public governance model are presented in Table 2.

Table 2 features of the new public governance in the management of a modern museum

\begin{tabular}{|c|c|c|c|c|}
\hline & $\begin{array}{l}\text { Institutional } \\
\text { values }\end{array}$ & $\begin{array}{l}\text { Governance } \\
\text { principles }\end{array}$ & $\begin{array}{l}\text { Management } \\
\text { measures }\end{array}$ & $\begin{array}{l}\text { Internal, } \\
\text { external } \\
\text { communication }\end{array}$ \\
\hline \multirow{2}{*}{$\begin{array}{l}\text { Abandonment } \\
\text { of the } \\
\text { hierarchical } \\
\text { management } \\
\text { model, coping } \\
\text { horizontal } \\
\text { governance } \\
\text { model }\end{array}$} & $\begin{array}{l}\text { values as a } \\
\text { unifying basis } \\
\text { for action }\end{array}$ & $\begin{array}{l}\text { employees } \\
\text { unifying } \\
\text { museum } \\
\text { vision and } \\
\text { mission } \\
\end{array}$ & $\begin{array}{l}\text { general objectives } \\
\text { and strategic } \\
\text { priorities }\end{array}$ & $\begin{array}{l}\text { for all } \\
\text { employees } \\
\text { available } \\
\text { information }\end{array}$ \\
\hline & $\begin{array}{l}\text { consultation } \\
\text { culture, reaction } \\
\text { to different } \\
\text { approaches }\end{array}$ & $\begin{array}{l}\text { bottom-up } \\
\text { management }\end{array}$ & $\begin{array}{l}\text { learning } \\
\text { organisation }\end{array}$ & $\begin{array}{l}\text { promoting } \\
\text { dialogue and } \\
\text { expression of } \\
\text { opinion }\end{array}$ \\
\hline \multirow{3}{*}{$\begin{array}{l}\text { Visitor } \\
\text { orientation } \\
\text { and } \\
\text { engagement }\end{array}$} & $\begin{array}{l}\text { focus on } \\
\text { audition }\end{array}$ & initiative & $\begin{array}{l}\text { marketing tools } \\
\text { used }\end{array}$ & \multirow{2}{*}{$\begin{array}{l}\text { studies are } \\
\text { carried out to } \\
\text { estimate the } \\
\text { quality of work }\end{array}$} \\
\hline & $\begin{array}{l}\text { involving } \\
\text { citizens }\end{array}$ & $\begin{array}{l}\text { involvement of } \\
\text { stakeholders }\end{array}$ & $\begin{array}{l}\text { responding to } \\
\text { stakeholders' } \\
\text { needs }\end{array}$ & \\
\hline & $\begin{array}{l}\text { more society } \\
\text { groups } \\
\text { inclusive } \\
\text { representation }\end{array}$ & multiculturalism & $\begin{array}{l}\text { knowledge about } \\
\text { audience }\end{array}$ & $\begin{array}{l}\text { tolerated } \\
\text { people } \\
\text { differences }\end{array}$ \\
\hline
\end{tabular}




\begin{tabular}{|l|l|l|l|l|}
\hline $\begin{array}{l}\text { Intersectoral } \\
\text { cooperation, } \\
\text { networking }\end{array}$ & $\begin{array}{l}\text { knowledge } \\
\text { generation } \\
\text { and mediation }\end{array}$ & $\begin{array}{l}\text { scratch } \\
\text { achievement of } \\
\text { objectives } \\
\text { cooperation }\end{array}$ & $\begin{array}{l}\text { knowledge } \\
\text { based } \\
\text { risk taking }\end{array}$ & $\begin{array}{l}\text { virtual } \\
\text { communication }\end{array}$ \\
\hline $\begin{array}{l}\text { The pursuit of } \\
\text { transparency } \\
\text { and } \\
\text { accountability }\end{array}$ & $\begin{array}{l}\text { accountability } \\
\text { to the public } \\
\text { and } \\
\text { transparency }\end{array}$ & $\begin{array}{l}\text { institutional } \\
\text { self - assessment }\end{array}$ & self-analysis & $\begin{array}{l}\text { preparation of } \\
\text { annual reports }\end{array}$ \\
\hline
\end{tabular}

Source: Anderson Gail, Reinventing the Museum. The Evolving Conversation on the Paradigm Shift. Second edition, Plymouth: AltaMiraPress, 2012.

The presented table reflects the four components of the new public governance model and their correlations with the essential principles of modern museum management. It is important to emphasize that the correlation between the presented governance model and modern museum governance is closely correlated and even often intertwined, making segment separation conditional. The essential segment is horizontal management - a decisionmaking system that aims to make the most efficient, optimal decisions possible through consultations with stakeholders, professionals in the field. Much attention is paid to the development of collaborative relationships that would serve the successful implementation of activities within and outside the organization. Contemporary museums work closely with non-governmental and private sector organizations to increase the attractiveness and quality of their activities and to pool financial resources for larger-scale projects. Orientation to visitors is especially important for contemporary museums - in order to survive in market conditions, contemporary museums must create activities that meet the expectations and needs of society in line with cultural products - museums are no longer institutions just for collecting and preserving historical values. According to Stephen (2007), evolving museums must continually take into account the needs of visitors and seek to meet them by expanding the range of services already available.

\section{THE EXPRESSION OF THE NEW PUBLIC GOVERNANCE IN LITHUANIAN MUSEUMS}

According to the data of the Department of Statistics of the Republic of Lithuania, in 2019 there were 107 museums, which are divided according to subordination and origin: national (4), republican (15), municipal (55), departmental (23), public institutions / non-state museums (10). The field of Lithuanian culture is a favorable environment for the existence of museums - since 2016 until 20194 new museums have been established in Lithuania. An 
important indicator emphasizing the aspect of the new public governance (visitor orientation, their involvement) is also reflected in the statistics - in Lithuania 2016 the museum was visited by 3981 thousand in 20195589 thousand visitors. The number of visitors to Lithuanian museums has increased by $40 \%$ during the last four years. This significant increase in the number of visitors to museums proves that museums apply the principles of the new public governance in their activities, focusing on the needs of visitors, creating new services that meet the needs of the population. Another very important statistical indicator proving that museums pay more and more attention to the publicity of the accumulated museum values and increasing their accessibility to the public is the share of exhibits exhibited in museums in relation to the total number of preserved exhibits. This percentage changed in a positive direction - in 2015 amounted to 4.6\%, and in 2019 already reached $5.3 \%$.

Another very important aspect is the interest of young people, their involvement in museum activities is educational programs. In Lithuania, museums provided a very wide range of educational activities - 2,538 different programs. About 620 thousand students participated in the educational programs organized by the museums. It is important to mention that the Ministry of Culture of the Republic of Lithuania in 2018 created a new platform for educational activities (Cultural passport), a funding mechanism for the implementation of this measure in order to enable as many students in the country as possible to use the services of educational programs and thus expand their horizons outside the school.

In order to increase the accessibility of the exhibits stored in the funds, the Lithuanian National Museum of Art in 2010 created the Lithuanian Integrated Museum Information System. Visitors to this electronic platform can not only view digitized exhibits, but also virtual exhibitions organized by museums. Currently, the system contains 561596 digital objects, 488344 exhibits from 114 museum collections, 82 exhibits with video. Platforms of this nature have significantly increased the availability of museum values, especially in today's COVID-19 situation, when museums cannot be visited physically for long periods of time.

The Lithuanian Association of Museums plays a very important role in improving the activities of museums. This organization was established in 1995 by the team of active and experienced museologists. At present, the association has significantly expanded its activities and unites more than 100 Lithuanian museums. The Association of Museums takes care of the continuous improvement of the museum institution, carries out various modernization projects, organizes trainings for museologists, thus providing an opportunity to improve their 
professional qualifications. In 2018, a professional development program for specialists working in museums was implemented, which allowed for a systematic and consistent deepening of the knowledge of museum staff and the development of competencies required for the activities of modern museums. It is important to mention that in 2018, during the training of museologists, 16 training seminars were organized, in which 400 specialists working in museums from 76 museum partners improved their qualification. By conducting trainings, the association seeks to improve the prestige of museum activities in Lithuania and abroad.

Another manifestation of the new public governance in museums is the refinement of mission, vision and organizational values. All national and republican museums have refined these components, as well as most municipal and departmental museums. Non-state museums are also following the path of state museums and beginning to refine their mission and vision. It is also important to highlight the aspect of museum cooperation, networking. Museums closely cooperate with other cultural, educational, scientific, business, statutory institutions, non-governmental organizations. Closer cooperation is encouraged by today's trends in the field of culture, where the implementation of most operational projects requires partners from different spectrum and fields.

In Lithuania, the activities of museums are regulated by several main legal acts: the Law on Lithuanian Museums, the Lithuania 2030 Strategy, the Strategic Development Directions of Lithuanian Museums in 2015-2020, 2014-2020 national progress program.

Article 1 of the Law on Museums of the Republic of Lithuania defines "the system, classification and types of museums, their establishment, operation, termination and conversion, the accounting and protection of museum values and other relations relating to the operation of museums." The law provides a classification of museums: "museums are divided into national, republican, municipal, departmental and other." Article 21 part of that law defines the concept of a museum as revealing the close connection between today's museum and the new public governance model: "a legal person acting as a budgetary, public body or other legal entity established in accordance with a statutory to protect, restore, research, exhibit and popularize material and spiritual cultural values and natural objects." The Museum Council, the Association of Lithuanian Museums, which unite the country's museums and represent their position, occupy an important place in the network of museums. 2014-2020 The National Progress Program has been prepared in order to implement the State Progress Strategy Lithuania 2030. The Progress Program identifies two priorities related to culture: "Education, Science and Culture", "Culture".Objective 1.2.2 of Priority 1 "Public 
Education, Science and Culture" is presented as follows: "Preserve and actualize cultural heritage and raise awareness". The priority directions of this task are: "to develop the accessibility of documentary and cultural heritage in the electronic space, to digitize and preserve products of artistic and cultural content, to create e-content based on digital content. services and solutions; to modernize the museum so that it can be used for learning and education, to implement interactive creative solutions, to adapt them to the needs of various social and age groups". The identified priority directions of the task reveal the manifestations of the essential features of the new public governance in modern museum management: the availability of exhibits in electronic space, the importance of digitization, modernization of expositions, adaptation of provided services to the needs of various social groups.

The vision of Lithuania's progress strategy "Lithuania 2030" emphasizes "the focus on ideas that would help Lithuania to become a modern country, open to the world and nurturing its national identity." Fostering national culture is one way to preserve a country's identity. One of the goals of the Active Society initiative is related to the provision of cultural services, cooperation in the field of culture: "To develop high-quality cultural services throughout the country in order to ensure cultural diversity and its accessibility. Encourage partnerships between culture and the various walks of life through the use of creative products and cultural services." The stated goal refines the institutional structure providing high-level services, reveals cooperation between cultural institutions and partnerships with other institutions. One of the goals of the "Learning Society" initiative is related to the institutional structure of cultural institutions, investment in their development and digitization: "To form a rich cultural environment by investing in the development of public cultural institutions and their integration, promoting public participation in cultural processes. Facilitate cultural dynamism, in particular by promoting international cultural exchanges and the transnational mobility of creators. To increase the dissemination of culture in Lithuania and foreign countries, paying special attention to the digitization of cultural heritage and contemporary cultural content."

In the strategic development directions of Lithuanian museums in 2015-2020, it is stated that "the constantly changing environment influencing museums also changes the nature of museum work and the tasks for which museum staff need new skills and knowledge. Therefore, the planning of the competencies of the specialists working in museums, the improvement of the existing competencies, and the development of new skills are necessary elements of the activities of modern museums ". The continuous systematic investment of museums in improving the skills of museologists as specialists significantly contributes to the 
increase in the quality of services provided by museums. By sharing their experience during seminars with their colleagues from all over Lithuania, museologists have the opportunity to understand the problems of the overall field of Lithuanian culture in the field of museology, emerging challenges, visitor needs, expectations and innovative measures already applied in Lithuanian museums.

\section{CONCLUSION}

The specifics of the activities of a modern museum are significantly different from a retrospective point of view - museum institutions are perceived not only as places for collecting and storing exhibits, but special attention is paid to visitors and the development of services that meet the needs of society.

The modernization of museums, the management of which is based on the new model of public governance, is reflected in 4 essential characteristics (abandonment and horizontalisation of the hierarchical model, visitor orientation, cross-sectoral cooperation, transparency and accountability), which include institutional values, governance principles the prism of management tools, internal and external communication.

Lithuanian museums are rapidly modernizing due to very favorable conditions - the existence of the ICOM National Committee in Lithuania, the establishment of a museum council, which takes care of the development of museums and staff, the creation of a digital Lithuanian integrated museum information system (LIMIS) and a flexible legal framework.

\section{REFERENCES:}

[1] Anderson G. (2012). Reinventing the Museum. The Evolving Conversation on the Paradigm Shift. Alta Mira Press, Plymouth.

[2] Bolívar, M. P. R., Meijer, A. J. (2015). Smart Governance Using a Literature Review and Empirical Analysis to Build a Research Model. Social Science Computer Review, vol. 34 , no. 6, p. 1-20.

[3] Bovaird, T., Loeffler, E (2012). From engagement to co-production: How users and communities contribute to public services. Routledge, New York.

[4] Bovaird, T., Loeffler, G., Parrado, S (2015). Activating citizens to participate in collective co-production of public services. Journal of Social Policy, vol. 44, no. 1, p. 1-23.

[5] Frederickson, H., Smith, K.B., Larimer W. C., Licari , M. (2016). The Public Administration Theory Primer. Westview Press, Boulder. 
[6] Guogis, A. (2010). Naujasis viešasis valdymas Smalskys, V. (Editor), Viě̌asis valdymas. Mykolo Romerio universitetas, Vilnius, p. 137-149.

[7] Howlett, M., Kekez A., Poocharoen O. (2017). Understanding Co-Production as a Policy Tool: Integrating New Public Governance and Comparative Policy Theory. Journal of Comparative Policy Analysis: Research and Practice, vol. 19, no. 5, p. 487-501.

[8] ICOM Statutes, (2007), from http://archives.icom.museum/hist_def_eng.html, accessed on 2021-03-05.

[9] Jonikaitè, E., Juknevičienè, V., Mikolaitytė, J. (2016). Naujojo viešojo valdymo transformacija: sumanumo dimensija. Ekonomika ir vadyba: aktualijos ir perspektyvos, vol. 38 , no. 1 , p. 39-48.

[10] Lietuvos muziejų strateginès plètros kryptys 2015 - 2020 m., Nr. IV-247, (2015-0423).

[11] 2014 - 2020 m. nacionalinès pažangos programa, Nr. 1482, (2012-11-28, supp. 201612-13).

[12] Lietuvos pažangos strategija „Lietuva 2030“, Nr. XI-2015, (2012-05-15).

[13] LR Muziejų ịstatymas, Nr.XIII-1750, (1995-06-08, supp. 2021-01-01).

[14] Milkintas, R. (2020). Meno kolekcionavimas: tautodailès aspektas. Tautodailès metraštis, vol. 41, no. 3, p. 27-30.

[15] Milkintas, R. (2020). Sumanus miesto kultūros valdymas. Magistro darbas. Šiaulių universitetas, Šiauliai.

[16] Morgan, D. F., Shinn, C. W. (2014). The Foundations of New Public Governance, Morgan, D. F. \& Cook, B. J. (Editors.), New Public Governance: A Regime-Centered Perspective. M. E. Sharpe, England, p. 3-12.

[17] Sandell, R., Janes, R. (2007). Museum Management and Marketing. Routledge, Oxon.

[18] Pedersen, K. H., Johannsen, L. (2018). New Public Governance in the Baltic States: Flexible Administration and Rule Bending. Public Performance \& Management Review, vol. 41, no. 2, p. 1-20.

[19] Scholl, H. J., Scholl, M. C. (2014). Smart Governance:A Roadmap for Research and Practice. Humboldt University Campus, Berlin.

[20] Stanislovaitienė, J. (2016). Expression of Smart Public Governance Dimensions: The Case of Lithuania. Kaunas University of Technology, Kaunas.

[21] Stephen, W., E. (2007). From Being about Something to Being for Somebody. The ongoing Transformation of the American Museum, Richard, S., Robert R. (Editors.), Museum Management and Marketing. Routledge, Oxon. 
[22] Strokosch, K., Osborne, S. P., (2020). Debate: If citizen participation is so important, why has it not been achieved?. Public Money \& Management, vol. 40, no. 1, p. 8-10.

[23] Vicente E., Camarero C., Garrido M. J., (2012). Insights into Innovation in European Museums. The Impact of Cultural Policy and Museum Characteristics. Public Management Review,vol. 14 no. 5, p. 649-679. 